\title{
The impact of supply chain practice on green hotel performance through internal, upstream, and downstream integration
}

\author{
Sautma Ronni Basana ${ }^{a}$, Widjojo Suprapto ${ }^{a}$, Fransisca Andreani ${ }^{a}$ and Zeplin Jiwa Husada Tarigan ${ }^{b^{*}}$
}

${ }^{a}$ Department of Management, Petra Christian University, Siwalankerto 121-131, Surabaya, Indonesia

${ }^{b}$ Department of Master Management, Petra Christian University, Siwalankerto 121-131, Surabaya, Indonesia

A B S T R A C T

\section{Article history:}

Received June 18, 2021

Received in revised format May

20, 2021

Accepted September 222021

Available online

September 222021

Keywords:

Supply chain practice

Upstream integration

Downstream integration

Internal integration

Green performance

\begin{abstract}
The company builds communication and collaboration with suppliers and customers to increase competitiveness in the supply chain flow. The organization's ability to involve suppliers and customers in business activities to achieve efficiency and effectiveness is one of the objectives of supply chain practice. The distribution of questionnaires directly to hotel practitioners was 25 respondents, and 65 respondents obtained the distribution of google form links. The results showed that supply chain practices with supplier relationship management and quality information sharing activities could increase internal and upstream integration and not directly impact downstream integration. Internal integration with data integration activities accurately and coordination between functions on an ongoing basis can affect upstream and downstream integration and green hotel performance. Upstream integration and downstream integration with joint decision activities and planning synchronization with external parties can directly impact green hotel performance. They were increasing the market share and image of the hotel with the implementation of caring for the environment. This research contributes to hotel practitioners adopting practical supply chains in building internal and external integration to increase competitiveness and theoretical contribution to developing supply chain theory and green performance.
\end{abstract}

(c) 2022 Growing Science Ltd. All rights reserved.

\section{Introduction}

The development of the manufacturing and services industry is highly dependent on the growth of customers and the ability of suppliers to provide materials as needed. The company tries to connect suppliers and customers to the company's internal systems in an integrated manner to communicate and coordinate quickly and precisely (Sundram et al., 2016). The company's ability to integrate suppliers and customers into the internal business is called supply chain management (Kang et al., 2018). The company implements supply chain management intending to produce products or services that provide service processes and processes to make products efficiently and effectively. The company's ability to utilize the supply chain by implementing increases competitiveness on an ongoing basis. The company can also provide good service to customers and impact the development of the company's suppliers. The services and manufacturing industry must coordinate internally and externally in implementing the supply chain in a practical way (Phan et al., 2019). Supply chain practices are carried out by companies in the supply chain flow, starting from a supplier-focused role, internal coordination within the company, and a customerfocused role (Tarigan et al., 2021; Al-Shboul et al., 2017; Gorane \& Kant, 2016). Supply chain practice is a core business for the company (supplier management, process control, improvement, top management support, and customer focus) and supporting industry for culture-oriented practices companies (Truong et al., 2017). Supply chain practice can impact the performance of retail companies (Tarigan et al., 2021; Jie \& Gengatharen, 2019). Supply chain practices in manufacturing companies in India can affect company performance (Gorane \& Kant, 2016). Activities carried out by the company as a form

* Corresponding author

E-mail address: zeplin@petra.ac.id (Z. J. H. Tarigan)

(C) 2022 Growing Science Ltd. All rights reserved.

doi: $10.5267 /$ j.uscm.2021.9.010 
of supply chain practice internally by conducting process control and improvement. Internal activities can build upstream integration by implementing supplier management. Internal activities also have an impact on downstream integration by running customer focus. Activities carried out by the company to understand customer desires and customer expectations. The company tries to communicate with suppliers to get quality materials according to the requirements set (Truong et al., 2017). Supply chain practice as a practice and activity adopted to produce an effective and efficient process in managing supply chain flow through coordination of supply, demand, and relationships to meet customer expectations (Al-Shboul et al., 2018). Supply chain practice can help companies to improve the efficiency and effectiveness of the company's operations. Supplier collaboration built by the hotel with the supplier. Hotels involve suppliers in solving problems faced following the provisions in building a purchasing strategy (Tarigan et al., 2020). Sustainable development for hotels involves management, employees, customers, suppliers, local government, financial support from parent firms as stakeholders to be responsible and focused on getting eco-certified (Prud'homme \& Raymond, 2016). Green supply chain practice for hotels in building cooperation with suppliers and customers to minimize environmental impact. Tourism business industry organizations ask suppliers to provide environmentally friendly materials and implement processes that minimize environmental impacts (Nguyen et al., 2020). Hotels can build market intelligence in the hope of being able to adapt internal conditions quickly to changes that occur in customers, competitor developments, technological developments, and regulations (Alnawas \& Hemsley-Brown, 2019).

Supply chain integration, which consists of internal integration, supplier integration, and customer integration, can impact organizational flexibility as a form of company performance (Shukor et al., 2020). Internal integration in manufacturing companies can increase external integration, inter-plant coordination, and operational performance (Cheng et al., 2016). Hotels can implement information technology to support employee performance. The use of technology correlates with an increase in the ability of individual employees to understand the function of information technology systems (Ratna et al., 2018). Information technology can influence supply chain practice's effect on retailer performance (Tarigan et al., 2021). Information integration for the hotel industry can impact the purchasing strategy to provide real-time data reports to suppliers (Siagian et al., 2019). Information technology used in Romanian hotels for front offices is used for customer check-in, room arrangement and control, and customer payment systems (Oltean et al., 2014). The company tries to build strong relationships between functions through communication, coordination, and effective relationships to improve flexibility in anticipating change (Khalaf \& El Mokadem, 2019). This condition has an impact on the hotel to share information with the customer through marketing information. Supply chain integration can impact business performance through supply chain flexibility and resilience but has no impact if it is through an innovation system (Siagian et al., 2021). Green activities in the industry are usually found in the use of environmentally friendly materials, the substitution of environmentally friendly raw materials, the use of supporting materials with ecologically friendly considerations, considering designs that can use a relatively small space, and the use of relatively short assembly times, optimizing processes to reduce waste and emissions, use technology that can save energy for the organization, carrying out recycling during the process phase and carrying out total quality that refers to international environmental standards (Cosimato and Troisi, 2015). In addition, green hotels are practically applied based on employee perceptions through an investigation process that is put forward with clean water and sanitation, affordable and clean energy, responsible consumption and production activities, and responses to climate change (Abdou et al., 2020).

Implementation of a green hotel by reducing food waste in the supply chain flow, then each department is advised to measure the number of components needed. Accurate calculations are required to buy food in large quantities to avoid overpackaging (Abdou et al., 2020). The current role of the hotel is not only used for resting places but also meeting, incentives, conventions, and exhibition activities. Organizations and government parties continuously use hotels for their actions. Hotel activities can be carried out with suppliers and customers on an ongoing basis in the supply chain management flow (Siagian et al., 2019). The hotel's ability to implement green supply chain practices in Vietnam can provide a good destination image for tourists visiting the north of Vietnam (Do et al., 2020). Vietnam Tourism Industry (VTI) capability in green supply chain practice by considering environmentally friendly products and processes according to customer wishes. Green purchasing set at hotels by considering the need for environmentally friendly materials can provide employee interest in implementing activities to support green operations (Basana et al., 2021). Hotel management in determining marketing management to understand customer needs. The supplier strategy used by the hotel to coordinate the procurement of quality materials. The hotel carries out the relationship between customers and suppliers to support sustainable development to reduce the negative impact on environmental damage (Prud'homme and Raymond, 2016). Hotel performance is generally determined by the occupancy rate, profit, and adaptability, supported by the development of information technology (Oltean et al., 2014).

With the hotel's ability to provide recycled products and eco-green products for efficiency, the hotel can increase performance by reducing energy consumption and providing efficiency in services (Tarigan et al., 2020). Green hotels are widely applied in using materials that can be recycled, using materials that can be separated and reused. Hotel activities focus on the green by using environmentally friendly materials, maintaining processes with relatively small pollution, saving energy use, improving service procedures, adding environmental protection ideas to the training carried out (Basana et al., 2021). In addition, green hotels can impact operational costs by reducing permanent costs and low investment costs to increase profits and increase customer satisfaction (Buunk \& Van der Werf, 2019). Based on the explanation above, few studies discuss supply chain practice on hotel objects that involve integration with upstream supply chain and downstream supply chain parties in improving green performance. Previous research still explains the relationship between the two constructs but has 
not been carried out simultaneously. This study has five main objectives: first, to examine supply chain practice against internal hotel integration, and second, to explore the relationship between supply chain practice and external integration, namely upstream integration and downstream integration. Third, examine the relationship between internal and external integration, namely upstream and downstream integration. Fourth, read the relationship of internal integration to green hotel performance. Lastly, fifthly examine the relationship of external integration, namely upstream integration and downstream integration, to green hotel performance.

\section{Literature Review}

\subsection{Supply Chain Practice}

Companies try to involve external and internal roles to build competitiveness on an ongoing basis to achieve efficiency and effectiveness (Tarigan et al., 2021; Sundram et al., 2016). The activities carried out by the company practically by involving suppliers and customers and empowering internal roles are called supply chains (Tarigan \& Siagian, 2021). Supply chain practice can be divided into three by paying attention to the position in the supply chain flow, namely the main activity focuses on the role of the supplier, the main activity focuses on the internal function of the company, and the main activity focuses on the part of the customer (Al-Shboul et al., 2017; Jie, \& Gengatharen, 2019; Tarigan et al., 2021; Sundram et al., 2016). In Vietnamese hotels, green supply chain practices are tourism enterprises with packaging waste, economical transport, product recycling, and green capability (Nguyen et al., 2020). Supply chain practice activities in Indian manufacture are organizational culture, customer relationship, information and communication technology, benchmarking and performance measurement, lean manufacturing, agile manufacturing, and supplier relationship, outsourcing, information sharing, just in time manufacturing, green SCM, reverse logistics, postponement, vendor managed inventory and radio frequency identification (Gorane \& Kant, 2016). Supply chain practice with activities that focus on the role of suppliers, including strategic supplier partnerships (Sundram et al., 2016; Gorane \& Kant, 2016; Al-Shboul et al., 2017; Tarigan et al., 2021), information sharing with suppliers (Sundram et al., 2016; Al-Shboul et al., 2017; Jie, \& Gengatharen, 2019), quality of supplier information sharing (Al-Shboul et al., 2017; Sundram et al., 2016; Tarigan and Siagian, 2021), strategic alliance with suppliers (Jie, \& Gengatharen, 2019); supplier collaboration (Al-Shboul et al., 2018); flexibility with suppliers (AlShboul et al., 2018). Supply chain practice with the primary activity role focusing on the customer, including sharing information with the customer (Al-Shboul et al., 2017; Jie \& Gengatharen, 2019; Al-Shboul et al., 2018), quality of customer information sharing ( Al-Shboul et al., 2017; Sundram et al., 2016), customer relationship management (Al-Shboul et al., 2017; Sundram et al., 2016; Jie, \& Gengatharen, 2019; Tarigan et al., 2021 ), Postponement (Al-Shboul et al., 2017; Sundram et al., 2016). Supply chain practice with main activities focused on internal coordination of the company, including information sharing with internal companies (Al-Shboul et al., 2017; Jie and Gengatharen, 2019; Sundram et al., 2016; Tarigan et al., 2021), quality of internal information (Gorane \& Kant, 2016; Al-Shboul et al., 2017; Sundram et al., 2016), implementation of lean thinking (Jie, \& Gengatharen, 2019; Al-Shboul et al., 2017; Al -Shboul et al., 2018), integration intensity (Gorane and Kant, 2016; Al-Shboul et al., 2018), agreed with vision and goals (Sundram et al., 2016), usage of internet (Al-Shboul et al., ., 2018) and risk and reward sharing (Sundram et al., 2016). Supply chain practice which consists of upstream supply chain practice, the focal company in the production process, and downstream supply chain practice, can impact sustainability (Govindan et al., 2014). This study establishes indicators for supply chain practice in hotels, namely customer relationship management, supplier relationship management, quality information sharing, and supports the objectives set by the company.

\subsection{Supply chain management Integration}

The business that companies use to integrate company activities within the organizations internal with the external organization is known as supply chain management integration (Kang et al., 2018; Sundram et al., 2016). Supply chain management integration that connects business processes, activities, functions, and places between the company and its customers is known as downstream integration. Between the company and suppliers is the definition of upstream integration and between business functions within the company. Companies try to control internal processes and make improvements to build external relationships through supplier management and customer focus (Truong et al., 2017). Supply chain integration in a company is measured by sharing information about material/product needs, involving partners in product development, sharing company-level inventory, sharing company production planning with external parties, and actively coordinating with external parties as company partners (Siagian et al., 2021). Manufacturing companies increase operational performance by integrating internal and external, and inter-plant coordination (Cheng et al., 2016).

\subsubsection{Internal Integration}

Fast coordination between organizational functions in integrated activities using integrated information technology (Suprapto et al., 2017). Internal integration occurs between the manufacturing and purchasing departments in sharing information, and joint decisions can improve coordination between functions in the company (Cheng et al., 2016). Integration between warehouses in providing materials with the production department when they need material supply can use an integrated information system to determine the needs of day-to-day activities. Integration between functions is determined by the 
existence of process control and improvement to produce quality products, reduce process variance, and minimize errors made by employees (Truong et al., 2017). Integration between the delivery function and the finished goods warehouse function provides the types of products ready to be delivered to customers. Integration between the production planning department and the marketing department in determining the production process schedule. Internal integration supply chain used in enterprise resource planning applications is determined by measuring items inventory data integration between functions within the company's internal, data integration between tasks within the company's internal, real-time integration, and cross-functional process improvement (Pirmanta et al., 2021). The integration of internal functions in the company can provide efficient and effective processes (Kang et al., 2018). The internet of things used by hotels using information technology in real-time and the availability of information for hotel residents can satisfy customers (Basana et al., 2021). Information integration as a system in hotels can have an impact on cross-functional internal organization with the indicators set are data integration between functions running well, reports used between departments are updated continuously, employees can access data on time, and data improvement in the organization's internal hotels can be made online (Hotlan et al., 2019). Internal integration is integration between functions within the company as measured by data integration between processes running well, enterprise application integration running normally, inventory data integration, real-time searching inventory, and real-time searching logistics data (Shukor et al., 2020). Internal integration occurs between functions within the organization to achieve effectiveness and efficiency as measured by communication cross functions, coordination cross functions, and affective relationships (Khalaf \& El Mokadem, 2019). The use of information technology in hotels is measured by technological reliability, data processing speed, control, and minimal troubleshooting, technology flexibility, and technology compatibility (Ratna et al., 2018). In carrying out internal integration in Romanian hotels, information technology uses the management system medallion, eXpresSoft, and standard Microsoft office software (Oltean et al., 2014). Internal integration is determined with the construct measurement items data integration across internal functions, data integration in real-time, accurate data integration, and coordination cross functions on an ongoing basis.

\subsubsection{Downstream Integration}

Coordination built by the company with the customer is also known as backward integration. Information about product needs with product order processes and forecasting processes carried out by the company on demand (Sundram et al., 2016). The coordination built by the company with the customer can also be used to return products that are not following the organization's needs. The company builds information quality with the customer by sharing accurate, measurable, complete, reliable, and timely information, making it easier for customers to prepare. The indicators used by companies related to downstream with customers in the supply chain are customer relationships, information technology links with customers, information sharing with customers, customer involvement in the design, and customer involvement in quality in companies in Vietnam (Phan et al., 2019). Customer integration in the manufacture and services industry in Malaysia is measured by the items of the relationship level with the primary customer, the computer system level in placing an order for the product, the level of information sharing with the customer, the communication built with the customer and the fast-ordering system by the primary customer (Shukor et al., 2020). The integration occurs between the company and the customer by focusing on customer needs through new product/service development activities and after-sales services to understand current customer needs and customer expectations in the future (Truong et al., 2017). External supply chain integration with the customer is determined by measuring information sharing with customers, improving customer processes, long-term relationships with customers, joint decision making with customers, and synchronizing planning with customers through enterprise resource planning applications (Pirmanta et al., 2021). Downstream Supply chain practice proposed by Govindan et al. (2014), namely lean (just in time, delivery flexibility, customer relationship), resilient (flexible transportation, silent product, and demand base management), and green (reverse logistics, environment monitoring by the customer, and discuss with the customer). The company can postpone the process by holding the product to be sent to the customer when the stock position at the customer is still adequate, and the company delays assembling the product according to the customer's request so that it can provide company integration with the customer (Sundram et al., 2016). Explanation about downstream integration, this research determines the construct measurement items are improving the process with customer, the joint decision with the customer, synchronizing planning with the customer, and sharing quality information with the customer.

\subsubsection{Upstream Integration}

Upstream supply chain practice was developed by Govindan et al. (2014), namely lean (supplier relationship, just in time, supplier involvement), resilient (sourcing strategy, flexible sourcing, developing visibility), and green (environmental collaboration with suppliers, encourage suppliers to take return material, certification suppliers). The company's integration with the supplier is also called supplier integration (Kang et al., 2018). First, the company obtains materials from suppliers and determines the amount of material needed and specifications according to the criteria set by the company in deciding order qualifications (Cheng et al., 2016). Then, the company's purchasing department builds coordination and integration with suppliers to provide the materials needed with the correct quantity, quality, and delivery time (Sundram et al., 2016). The indicators used to measure the upstream supply chain in manufacturing companies are supplier selection, information technology link with suppliers, information sharing with suppliers, supplier involvement in the design, supplier involvement in quality, and supplier partnership (Phan et al., 2019). The integration established by the company with the supplier by implementing supplier management so that the communication and collaboration that is built can provide standard materials 
with the required quality and specifications (Truong et al., 2017). Supply chain external integration with the customer as the company's focus is measured by sharing information with customers, improving the process with customers, long-term relationship with customers, joint decision making with customers, and synchronizing planning with customers through enterprise resource planning applications (Pirmanta et al., 2021). The company's ability to communicate and integrate with suppliers will impact hotels when they get environmentally friendly materials and get materials that have a longer lifetime (Sautma et al., 2021). Hotels rely on a purchasing strategy to build collaborations with suppliers in providing eco-labeled products and providing products that can be recycled and meet the requirements set out following government regulations (Tarigan et al., 2020). The measurement items used in customer integration for the manufacture and services industry in Malaysia are determined by the level of information sharing with the leading suppliers, quick ordering systems with suppliers, the level of partnership with the main suppliers, the level of stability in supplying raw materials and the level of participation in determining the planning and production process. Shukor et al., 2020). Collaboration that hotels use with their suppliers through sharing of information and ideas to increase efficiency. Hotels involve suppliers in solving problems they face to be faster and more efficient (Tarigan et al., 2020). Explanation about upstream integration, this research determines the construct measurement items improve the process with suppliers, joint decisions with suppliers, synchronize planning with suppliers, and share quality information with suppliers.

\subsection{Green Hotel Performance}

The hotel's ability to provide environmentally friendly products or processes following customer requests, at the same time, pressure for hotels to carry out business activities (Do et al., 2020). Green performance is for organizations to increase their competitiveness with improved efficiency, quality improvement, productivity improvement, and cost-saving factors (Cosimato \& Troisi, 2015). The ability of hotels to run green hotels to improve hotel performance by implementing green purchasing, green operations, using information technology, and improving employee behavior on an ongoing basis (Basana et al., 2021). Hotel performance as a form of economic performance in the hotel industry is measured by sales growth, market growth, room occupancy rate, income from online reservations through information technology, and the percentage of income from overseas customers (Alnawas \& Hemsley-Brown, 2019). Moliner et al. (2012) stated that the hotel industry's performance is measured by financial performance, namely occupancy rate, income per room, gross profit per room, wealth creation, and generate profit. Hotel performance measurement of stakeholder satisfaction is measured by indicators of customer satisfaction level and employee satisfaction level. Hotel performance is measured on three dimensions of efficiency: increasing profits, effectiveness in rising occupancy rates, and adaptability in increasing income generation with new services (Oltean et al., 2014). Green Vietnam's tourism enterprises are set with hotel performance, namely Environmental performance, reputation, competitiveness, and financial performance (Nguyen et al., 2020). Green hotel performance is used to identify hotel operational performance, which can minimize waste and reduce the use of electrical energy to be more efficient (Tarigan, 2020). The Green Key eco-label in the hotels and Bed \& Breakfasts industry was obtained with several reasons for its application, including providing a better impact on the environment around the hotel, providing a good image for the organization, rules that apply to each industrial sector, ecolabeling able to increase profits, and eco-label can provide increased competitiveness (Buunk \& van der Werf, 2019). The use of information technology determines the increase in hotel performance with indicators of check-in online, increasing response to customers, increasing the level of services, and checking out in real-time (Siagian et al., 2019). Hotel performance measurements in implementing green include being able to reduce waste, being able to reduce energy consumption, and being able to provide efficient services (Tarigan et al., 2020). Hotels always try to implement green in business processes to improve the hotel's image for customers, reduce hotel operational costs, increase market share, and commit to environmental development (Abdou et al., 2020). This study sets out green hotel performance measurement items, namely improving hotel image for customers by implementing green hotels, reducing hotel operational costs by using environmentally friendly products, increasing market share through environmental care, and hotel commitment to ecological development (Buunk \& van der Werf, 2019; Abdou et al., 2020; Tarigan et al., 2020)

\section{Relationship between Research Concepts}

\subsection{The relationship between supply chain practice concepts and supply chain integration}

This sustainable ERP (enterprise resources planning) is defined as a place for internal integration and external integration used by manufacturing companies to keep data integration between functions running well and stable system integration between functions (Suprapto et al., 2017). The company upgrades software and hardware according to developments and maximizes technology utilization to improve performance (Pirmanta et al., 2021). Supply chain management integration can impact operational firm performance by increasing customer services, product quality, delivery dependability, delivery speed, and flexibility of volume (Vafaei-Zadeh et al., 2020). Supply chains practice in the company internally by sharing information between functions and departments can make coordination and communication, and data integration between departments run well (Sundram et al., 2016). Effectiveness and efficiency are one of the company's goals in improving company performance by building communication, internal coordination of the company with external parties to increase flexibility for customers (Khalaf \& El Mokadem, 2019). 
As indicated by internet usage, supply chain practice can provide increasing internal integration for the internal integration of manufacturing companies (Al-Shboul et al., 2018). Supply chain practices in companies with internal lean practice concepts can increase supply chain internal integration (Al-Shboul et al., 2017). Supply chain practices that focus on suppliers with a supply strategic partnership dimension (Tarigan \& Siagian, 2021) have an impact on upstream integration in supply chain integration with the organization's ability to assist suppliers in improving product quality and involve key suppliers in setting planning activities and organizational goals (Sundram et al., 2016). Supply chain practice in companies with quality of information sharing influences customer responsiveness in manufacturing companies (Al-Shboul et al., 2017). The communication built by the company with the customer has a positive impact on integration with customers because the company always measures and evaluates customer satisfaction and prepares customer expectations in the future as a form of supply chain practice in customer relationships, so there is continuous use of information technology by customers. (Sundram et al., 2016). Supply chain practice in manufacturing companies with a strategic supplier partnership can impact supplier performance (Al-Shboul et al., 2017). Based on the explanation of the relationship between concepts, can formulate the research hypothesis:

\section{$\mathbf{H}_{1}$ : Supply chain practice has an impact on internal integration in the hotel industry. \\ H2: Supply chain practices have an impact on upstream integration in the hotel industry. \\ $\mathbf{H}_{3}$ : Supply chain practices have an impact on downstream integration in the hotel industry.}

\subsection{The relationship between the concept of internal integration and upstream integration}

Information integration used by the hotel can provide reports that are updated in real-time. Accessing data as needed can impact the purchasing strategy to build long-term relationships with suppliers (Siagian et al., 2019). Process control and development and improvements made by the company can build upstream integration to understand current customer needs and customer expectations in the future (Truong et al., 2017). Internal integration with good inventory data integration and data integration between the company's internal functions can impact upstream integration in manufacturing companies (Cheng et al., 2016). The formed upstream integration can increase long-term relationships with suppliers and synchronize company plans with suppliers (Pirmanta et al., 2021; Tarigan \& Siagian, 2021). Internal integration between departments within the company can impact increasing supplier collaboration by sharing information about inventory levels with suppliers and sharing forecasts about customer demand (Al-Shboul et al., 2018). Internal integration created from communication and coordination between functions impacts communication and coordination on the supplier side, namely, sharing inventory and forecasting data (Khalaf and El Mokadem, 2019).

$\mathbf{H}_{4}$ : Internal integration has an impact on upstream integration in the hotel industry.

\subsection{The relationship between the concept of internal integration and downstream integration}

Process control and improvement carried out by the company on an ongoing basis by involving cross-functional internally as a form of internal integration can build strong communication with suppliers in providing quality materials according to the specifications set (Truong et al., 2017; Suprapto et al., 2017). Internal integration with good inventory data integration and data integration between the company's internal functions to be able to provide internal information to the customer and have an impact on downstream integration in manufacturing companies by increasing long term relationships with customers and improving product/service processes to customers (Pirmanta et al., 2021). Supply chain integration is defined by the organization's ability to exchange information with customer partners online. Internal integration within the company with solid coordination between departments and teams between internal functions can solve problems in a stable manner capable of impacting customer focus (Al-Shboul et al., 2018). Internal integration with inventory data and forecasting processes can impact downstream integration through order flexibility, delivery flexibility, and volume flexibility (Khalaf and El Mokadem, 2019).

\section{H5: Internal integration has an impact on downstream integration in the hotel industry.}

\subsection{The relationship between the concept of internal integration and green hotel performance}

Quality information sharing within the company as a form of integration between functions cannot impact quality performance, cost performance, and delivery performance, which is included in the company's operational performance in Vietnam (Phan et al., 2019). The supply chain internal integration built by the company can impact firm performance in meeting quality products according to customer needs and expectations to increase customer satisfaction (Pirmanta et al., 2021; Suprapto et al., 2017). Internal integration in the services and manufacture industry with real-time searching level inventory and enterprise application integration, cross-functional internal does not impact increasing supply chain agility (Shukor et al., 2020). The integration built by the company using information technology, so that good cross-functionality occurs will impact green supply chain practice to improve performance in the tourism industry (Do et al., 2020). The hotel's ability to use information integration can increase hotel performance (Siagian et al., 2019). The company's internal integration 
can increase external flexibility capability as the company's performance towards services provided to customers (Khalaf and El Mokadem, 2019).

$\mathbf{H}_{6}$ : Internal integration has an impact on the green hotel performance industry.

\subsection{The relationship between the concept of upstream integration and green hotel performance}

Supplier integration in services and manufacturing industries with a level of strategic partnership and stability in supplying materials impacts supply chain agility, as shown in the reduction of product development cycle time and lead time (Shukor et al., 2020; Tarigan \& Siagian, 2021). Information sharing with suppliers and connecting internal information technology with suppliers can impact cost performance and not affect the quality and delivery performance of companies in Vietnam (Phan et al., 2019). The collaboration built by the company with suppliers as a form of upstream integration in improving the quality of product materials can impact the hotel's ability to save energy and water-saving practices to improve financial performance (Moliner et al., 2012). Supply chain external integration with upstream integration built by the company can impact firm performance in meeting quality products according to customer needs and expectations to increase customer satisfaction (Pirmanta et al., 2021).

H7: Upstream integration has an impact on the green hotel performance industry.

\subsection{The relationship between the downstream integration concept and green hotel performance}

Information sharing with customers and connecting internal information technology with customers can impact the company's operational performance in Vietnam (Phan et al., 2019). Customer integration in the services and manufacturing industry with the level of the company's relationship with customers and the level of sharing of market information has an impact on increasing supply chain agility (Shukor et al., 2020). The hotel's ability to understand the customer will be by collecting data integrated with the customer through the information system provided by the hotel, namely customer relationship management. The hotel hopes that customers can tell their experiences after getting service from the hotel. Good relationships with customers impact hotel performance through efficiency and effectiveness (Alnawas and Hemsley-Brown, 2019). Supply chain external integration with downstream integration built by the company by improving processes and joint decision making with customers can impact firm performance in meeting product quality and increasing customer satisfaction (Pirmanta et al., 2021).

$\mathbf{H}_{8}$ : Downstream integration has an impact on the green hotel performance industry.

Based on the explanation in the literature review and the relationship between concepts, this research can be defined as a conceptual research framework in Fig. 1.

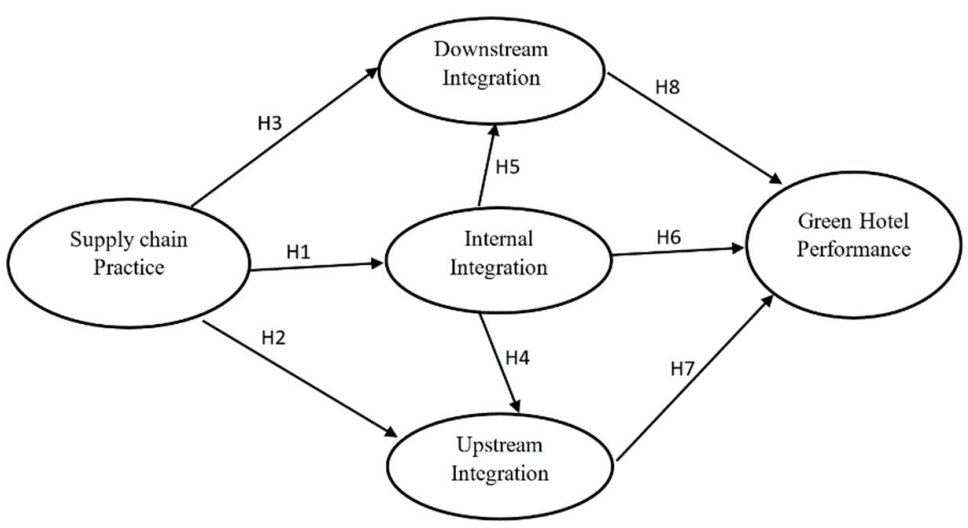

Fig. 1. Research Concept Framework

\section{Research Methods}

The growth of hotels in East Java has been established since the increasing business growth and one of the largest economic contributors in Indonesia. Most hotel growth in East Java is in budget hotels used by business people who travel relatively quickly. Data collection was carried out for two years in the period 2020 to 2021 due to the uncontrolled spread of COVID19, which imposed large-scale social restrictions in Indonesia. This condition results in data collection that cannot be carried out effectively. Data collection was carried out for hotels in East Java, and the research population was determined to be 3 , 
4, and 5-star hotels contained in the agoda.com application and the traveloka.com application totaling 265 hotels. Data is distributed in two ways, namely through questionnaires and through a form. The Google link requested to be filled in by hotel practitioners related to hotel supply chain practice activities. The distribution of the questionnaire using a Likert scale from strongly disagree (1) to strongly agree (5). The measurement items for supply chain practice are four items, internal integration four items, upstream integration four items, downstream integration four items, and green hotel performance four items. Data processing for all items was tested for validity and used the constructed variable for the reliability test using PLS (Partial Least Square). The research hypothesis test was obtained by bootstrap test on java web start software.

\section{Data Analysis}

The results of the questionnaire distribution by using direct distribution to visit hotels in East Java were 25 respondents. In comparison, the distribution via google form was sent via WhatsApp and Facebook and collected as many as 65 respondents from hotel practitioners. Thus, total data collection for the period 2020-2021 (two years) was 90 respondents. The results of descriptive analysis of respondents' answers and measurement test items with validity and reliability tests are shown in Table 1 .

Table 1

Descriptive analysis and Measurement test

\begin{tabular}{|c|c|c|c|c|c|}
\hline Item Measurement & Mean & Std. Deviation & $\begin{array}{c}\text { Loading } \\
\text { factor }\end{array}$ & $\begin{array}{l}\text { Composite } \\
\text { Reliability }\end{array}$ & Result \\
\hline Supply Chain Practice & 4.266 & & & 0.849 & Reliable \\
\hline SCP1 (Customer relationship management) & 4.312 & 0.609 & 0.784 & & Valid \\
\hline SCP2 (Supplier relationship management) & 4.344 & 0.592 & 0.815 & & Valid \\
\hline SCP3 (Quality information sharing) & 4.297 & 0.604 & 0.775 & & Valid \\
\hline SCP4 (Support objectivity determined by the company) & 4.109 & 0.615 & 0.683 & & Valid \\
\hline Internal Integration & 4.156 & & & 0.779 & Reliable \\
\hline II1 (Integration of data between internal functions) & 4.203 & 0.642 & 0.595 & & Valid \\
\hline II2 (Integration of data in real-time) & 4.297 & 0.490 & 0.585 & & Valid \\
\hline II3 (Integration of data accurately) & 3.969 & 0.865 & 0.838 & & Valid \\
\hline II4 (Coordination between functions continuous) & 4.156 & 0.712 & 0.834 & & Valid \\
\hline Upstream Integration & 3.894 & & & 0.717 & Reliable \\
\hline UI1 (Improving process with suppliers) & 3.734 & 0.593 & 0.671 & & Valid \\
\hline UI2 (Joint decision with suppliers) & 4.031 & 0.583 & 0.754 & & Valid \\
\hline UI3 (Synchronization of planning with suppliers) & 3.859 & 0.390 & 0.747 & & Valid \\
\hline UI4 (Sharing quality information with suppliers) & 3.953 & 0.372 & 0.660 & & Valid \\
\hline Downstream Integration & 4.270 & & & 0.834 & Reliable \\
\hline DI1 (Improving process with the customer) & 4.125 & 0.696 & 0.724 & & Valid \\
\hline DI2 (Joint decision with the customer) & 4.359 & 0.715 & 0.773 & & Valid \\
\hline DI3 (Synchronization of planning with the customer) & 4.344 & 0.643 & 0.705 & & Valid \\
\hline DI4 (Sharing quality information to the customer) & 4.250 & 0.586 & 0.779 & & Valid \\
\hline Green Hotel Performance & 4.133 & & & 0.806 & Reliable \\
\hline GHP1 (Improve the image of the hotel) & 4.281 & 0.572 & 0.633 & & Valid \\
\hline GHP2 (Reducing the operating costs of the hotel) & 3.734 & 1.034 & 0.820 & & Valid \\
\hline GHP3 (Enhancing market share through the care environment) & 4.219 & 0.624 & 0.855 & & Valid \\
\hline GHP4 (The hotel's commitment to the development environment) & 4.297 & 0.604 & 0.844 & & Valid \\
\hline
\end{tabular}

Based on Table 1, found for the supply chain practice variable to get a mean value of 4.266, and the mean value of the measurement item between 4.109 - 4. 344. This shows that the hotel has carried out supply chain practice well and is carried out in activities work in hotels. The internal integration variable with a mean of 4.156 and the mean range value for each measurement item is at $3.969-4.297$; this indicates that internal integration at the hotel has been running well between one function and another. The housekeeping department, food and beverage section, front office, and others have data integrated with a system. The third variable is upstream integration, with a mean value of 3,894 , and the mean value of the measurement item is between 3,734-4,301. Illustrates that the company's relationship with suppliers has been going well and helps each other deal with the constraints that occur in the supply chain flow.

Downstream integration built by the company with distribution parties and customers is obtained with a mean value of 4.270 , and the mean value of the measurement item range is at $4.125-4,359$. This shows that the relationship between the hotel and the customer has been going very well. The information technology used by the company can be integrated with the customer, and the customer can customize the products/services produced by the hotel. As a result, the hotel's relationship with the customer looks very high, giving the customer a level of satisfaction and loyalty. Green hotel performance as the dependent variable is obtained with a mean value of 4.133 . The value of the measurement item range is at 3,734-4,297, and this shows that the organization has run a green hotel in daily activities and has an impact on company performance. Green hotels that are implemented positively affect hotels because they can improve their image and increase profits by reducing operational costs.

Based on Table 1. The lowest loading factor supply chain practice value is SCP4 (supporting the objectives set by the company) of 0.683 and the internal integration is II2 (Real-time data integration) of 0.585 . The lowest loading factor for 
upstream integration is UI4 (Sharing quality information with supplier) is 0.660, the lowest downstream integration is in DI3 (synchronization of planning with the customer) of 0.705 , and the lowest green hotel performance is GHP1 (improves the image of the hotel) of 0.633 . The loading factor for all measurement items has been above 0.500 so that it is declared valid. The value of composite reliability of supply chain practice is 0.849 , and internal integration is 0.779 , upstream integration is 0.717 , downstream integration is 0.834 , and green hotel performance is 0.806 . The composite reliability value of all variables obtained is above 0.700 , so it can meet the reliability requirements. The goodness of fit measurement model has met the requirements. The following analysis is carried out to test the research hypothesis as indicated by the bootstrapping test, and the results of the inner model (Table 2) and path coefficient (Fig. 2) are obtained.

Table 2

The Hypothesis Testing with Bootstrapping

\begin{tabular}{|c|c|c|c|c|}
\hline Direct Effect & original sample estimate & mean of subsamples & Standard deviation & T-Statistic \\
\hline $\mathrm{SCP} \rightarrow \mathrm{II}$ & 0.502 & 0.519 & 0.105 & 4.765 \\
\hline $\mathrm{SCP} \rightarrow \mathrm{DI}$ & 0.164 & 0.149 & 0.134 & 1.228 \\
\hline $\mathrm{II} \rightarrow \mathrm{DI}$ & 0.482 & 0.513 & 0.11 & 4.374 \\
\hline $\mathrm{SCP} \rightarrow \mathrm{UI}$ & 0.215 & 0.222 & 0.109 & 1.976 \\
\hline $\mathrm{II} \rightarrow \mathrm{UI}$ & 0.232 & 0.252 & 0.092 & 2.524 \\
\hline $\mathrm{II} \rightarrow \mathrm{GHP}$ & 0.258 & 0.269 & 0.103 & 2.163 \\
\hline $\mathrm{DI} \rightarrow \mathrm{GHP}$ & 0.410 & 0.398 & 0.099 & 4.162 \\
\hline
\end{tabular}

Based on the results in Fig. 1 and Table 2, tested the eight research hypotheses. The first hypothesis test of supply chain practice has an impact on internal integration in the hotel industry. The path coefficient value is 0.502 , and the t-statistics is 4.765 more than 1.96 , so the first hypothesis can be accepted. Therefore, it can be concluded that supply chain practice impacts internal integration in the hotel industry. It is testing the second hypothesis that supply chain practice affects upstream integration in the hotel industry. The path coefficient value is 0.215 (t-statistic 1.976), so the second hypothesis is accepted. It is concluded that supply chain practice has an impact on increasing upstream integration with suppliers in the hotel industry.

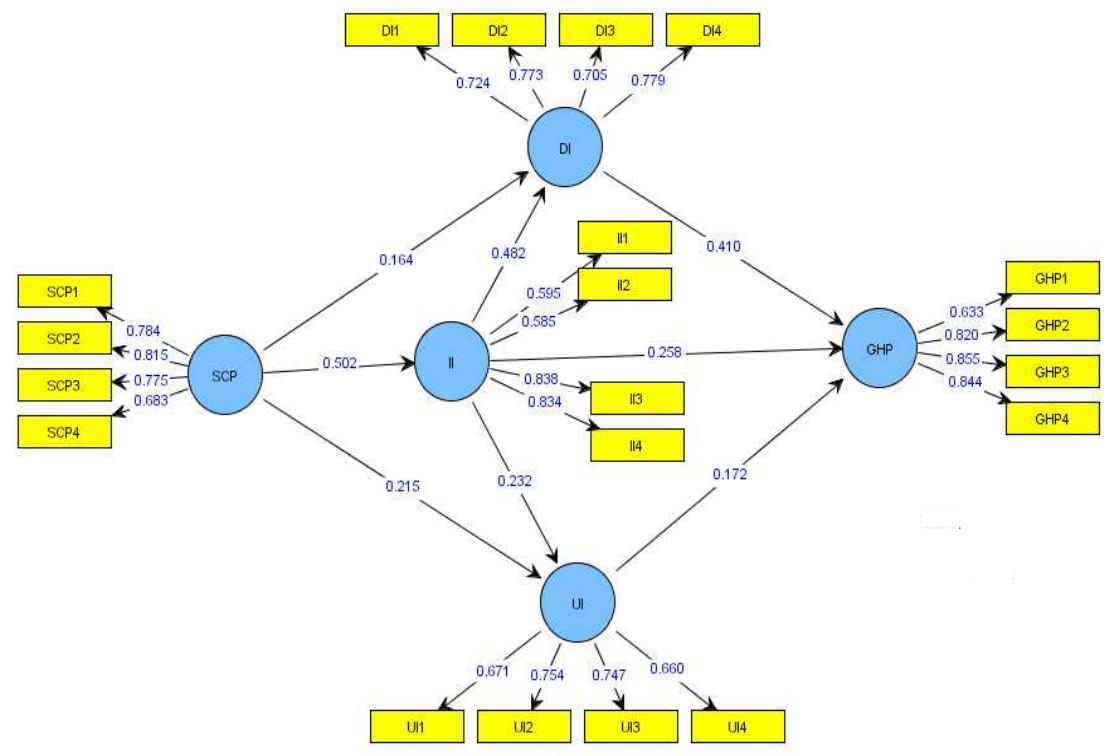

Fig. 2. Path Coefficient with PLS

The third hypothesis test of supply chain practice has an impact on downstream integration in the hotel industry. The path coefficient value is 0.164 (t-statistic 1.228), so the third hypothesis is rejected. The fourth hypothesis test concluded that supply chain practice could not impact downstream integration with customers in the hotel industry. However, internal integration has an impact on upstream integration in the hotel industry. The path coefficient value is 0.232 (t-statistic 2.524 ), so the fourth hypothesis can be accepted. Therefore, it can conclude that internal integration can impact upstream integration with suppliers to increase collaboration in the hotel industry. The fifth hypothesis tests internal integration has an impact on downstream integration in the hotel industry. The path coefficient value is 0.482 (t-statistic 4.374), so the fifth hypothesis can be accepted. It can conclude that internal integration has an impact on downstream integration with customers in the hotel industry.

The sixth hypothesis tests. Internal integration has an impact on the green hotel performance industry. The path coefficient value is 0.258 (t-statistic 2.163), so the sixth hypothesis can be accepted. It can be concluded that internal has an impact on 
green hotel performance with customers in the hotel industry. The seventh hypothesis test of upstream integration affects the green hotel performance industry. The path coefficient value is 0.172 (t-statistic 2.203 ), so the seventh hypothesis can be accepted. It can conclude that upstream integration impacts green hotel performance with customers in the hotel industry. The eighth hypothesis test of downstream integration has an impact on the green hotel performance industry. Values obtained a path coefficient of 0.410 (t-statistic 4162), the eighth hypothesis is unacceptable, so it concluded that downstream integration impacts performance with a green hotel in the hotel industry.

\section{Discussions}

The data analysis showed that the eight hypotheses and seven hypotheses could be accepted, and one hypothesis was rejected. The ability of hotels in East Java to implement supply chain practice activities can impact supply chain integration to improve green hotel performance. Based on the results of the hypothesis, it is stated that supply chain practice can affect internal integration in the hotel industry. The supply chain practice built by the hotel with quality information sharing internally and externally can accurately increase data integration and real-time data integration. The results of this hypothesis support research that states that supply chain practice can impact internal integration (Pirmanta et al., 2021; Vafaei-Zadeh et al., 2020; Sundram et al., 2016; Khalaf \& El Mokadem, 2019).

The second hypothesis is that supply chain practice has an impact on upstream integration in the hotel industry. Hotel supply chain practices by building supplier relationship management and quality information sharing increase supplier involvement in joint decisions. The company makes incentive communication and coordination with suppliers about company needs. The results of this study support the research results put forward by the statement that the supply chain practice used by hotels is to build upstream integration (Al-Shboul et al., 2018; Sundram et al., 2016; Al-Shboul et al., 2017). The third hypothesis is that supply chain practice has no impact on downstream integration in the hotel industry. The company's ability to build customer relationship management cannot improve customer processes and joint decisions with customers because many customers do not provide input for the hotel. Besides, hotel customers who make hotel reservations are not repeated in the short term and are different from manufacturing customers. Therefore, this study is different from research results that state that supply chain practice does not impact downstream integration (Sundram et al., 2016; Al-Shboul et al., 2017).

The fourth hypothesis is found that internal integration has an impact on upstream integration in the hotel industry. Internal integration that can provide increased data integration and coordination between functions on an ongoing basis can improve upstream integration because it improves supplier planning synchronization. This study supports the results of research that state that internal integration impacts upstream integration (Siagian et al., 2019; Truong et al., 2017; Pirmanta et al., 2021; Al-Shboul et al., 2018; Khalaf \& El Mokadem, 2019). The fifth hypothesis is found that Internal integration has an impact on downstream integration. Internal integration used by the organization as an integrated administration system in hotels with accurate data integration can increase customer satisfaction because it can share quality information. Again, this study supports the results of research that states that internal integration impacts downstream integration (Truong et al., 2017; Pirmanta et al., 2021; Al-Shboul et al., 2018; Khalaf \& El Mokadem, 2019).

The sixth hypothesis is found that Internal integration has an impact on green hotel performance. A well-organized internal data integration can impact reducing hotel operational costs by using environmentally friendly products. This study supports the results of research that Internal integration has an impact on green performance (Phan et al., 2019; Pirmanta et al., 2021; Shukor et al., 2020; Do et al., 2020; Siagian et al., 2019; Khalaf \& El Mokadem, 2019). The seventh hypothesis is that upstream integration has an impact on the green hotel performance industry. Upstream integration between the company and suppliers, resulting in joint decisions with suppliers, synchronization of planning with suppliers, and quality information with suppliers, can impact hotel commitments for environmental development and reduce hotel operating costs using environmentally friendly products. Again, this study supports the results of research that upstream integration affects green performance (Shukor et al., 2020; Phan et al., 2019; Moliner et al., 2012; Pirmanta et al., 2021; Tarigan and Siagian, 2021).

The eighth hypothesis of downstream integration has an impact on the green hotel performance industry. Downstream integration between the company and the customer by synchronizing planning with the customer and sharing quality information can increase green hotel performance. This increase can be seen from the hotel's image for customers by implementing green hotels and growing market share through caring for the environment. The study results confirm the results of research, which states that downstream integration impacts green performance (Phan et al., 2019; Shukor et al., 2020; Alnawas and Hemsley-Brown, 2019; Pirmanta et al., 2021). The study results indicate that supply chain practice is indispensable in developing hotel service systems in building integration within the internal and external organizations to improve hotel green performance. Improving the performance of hotels that care about the environment can provide increased competitiveness. This research contributes to the development of practical supply chain management theory and green performance. Practical contribution on how the important role of internal integration affects external integration for hotel industry practitioners in providing coordination and collaboration with suppliers and customers to increase competitiveness. 


\section{Conclusions}

Supply chain practice is essential for the manufacturing/services industry in improving efficiency and effectiveness. Based on the research results on hotel objects, it is found that supply chain practice by building quality information sharing, and supplier relationship management can increase internal integration and upstream integration. Supply chain practice for the hotel industry by building customer relationship management is not able to have a direct impact on downstream integration. Internal integration that occurs in the company with accurate data integration and coordination between functions on an ongoing basis can increase upstream and downstream integration. Internal integration can also directly impact green hotel performance by reducing hotel operational costs and using environmentally friendly products. Upstream integration and downstream integration can affect the green hotel performance industry by increasing the hotel's image for customers by implementing green hotels and growing market share through caring for the environment. Joint decisions with externals, synchronizing planning with externals, and sharing quality information can implement green hotels and increase market share through caring for the environment. Therefore, the implementation of supply chain practices can improve green hotel performance through supply chain integration.

\section{Acknowledgement}

This research is funded by the government Indonesia with PDUPT (Penelitian Dasar Unggulan Perguruan Tinggi) project number 009/AMD-SP2H/LT-MULTI-PDPK/LPPM-UKP/2021

\section{References}

Abdou, A.H., Hassan, T.H., \& Dief, M.M.E. (2020). A description of green hotel practices and their role in achieving sustainable development. Sustainability, 12, 9624, doi:10.3390/su12229624

Alnawas, I., \& Hemsley-Brown, J. (2019). Market orientation and hotel performance: investigating the role of high-order marketing capabilities. International Journal of Contemporary Hospitality Management, 31(4), 1885-1905. https://doi.org/10.1108/IJCHM-07-2018-0564

Al-Shboul, M.A.R., Barber, K.D., Garza-Reyes, J.A., Kumar, V., \& Abdi, M.R. (2017). The effect of supply chain management practices on supply chain and manufacturing firms' performance. Journal of Manufacturing Technology Management, 28(5), 577-609, https://doi.org/10.1108/JMTM-11-2016-0154.

AL-Shboul, M.A., Garza-Reyes, J.A., \& Kumar, V. (2018). Best supply chain management practices and high-performance firms: The case of Gulf manufacturing firms. International Journal of Productivity and Performance Management, 67(9), 1482-1509, https://doi.org/10.1108/IJPPM-11-2016-0257

Basana, S.R., Tarigan, Z.J.H., Suprapto, W., \& Andreani, F. (2021). The effects of internet of things, strategic green purchasing and green operation on green employee behavior: Evidence from hotel industry. Management Science Letters, 11(2), 2233-2242, DOI: 10.5267/j.msl.2021.4.006

Buunk, E., \& van der Werf, E. (2019). Adopters versus non-adopters of the green key eco-label in the Dutch accommodation sector. Sustainability, 11, 3563, doi:10.3390/su11133563

Cheng, Y., Chaudhuri, A., \& Farooq, S. (2016). Interplant coordination, supply chain integration, and operational performance of a plant in a manufacturing network: a mediation analysis. Supply Chain Management, 21(5), 550-568. https://doi.org/10.1108/SCM-10-2015-0391

Cosimato, S., \& Troisi, O. (2015). Green supply chain management: Practices and tools for logistics competitiveness and sustainability. The DHL case study. The TQM Journal, 27(2), 256-276. https://doi.org/10.1108/TQM-01-2015-0007

Do, A.D., Nguyen, Q.V., Nguyen, D.U., Le, Q.H., \& Trinh, D.U. (2020). Green supply chain management practices and destination image: Evidence from Vietnam tourism industry. Uncertain Supply Chain Management 8, 371-378, DOI: $10.5267 /$ j.uscm.2019.11.003

Gorane, S.J., \& Kant, R. (2016). Supply chain practices: An implementation status in Indian manufacturing organisations. Benchmarking: An International Journal, 23(5), 1076-1110

Jie, F., \& Gengatharen, D. (2019). Australian food retail supply chain analysis. Business Process Management Journal, 25(2), 271-287.

Kang, M., Park, K., \& Yang, M.G. \& Haney, M.H. (2018). Supply chain integration and coordination for international sourcing in the context of China's processing trade. Industrial Management \& Data Systems, 118(9), 1730-1748. https://doi.org/10.1108/IMDS-11-2017-0528

Khalaf, M.A., \& El Mokadem, M.Y. (2019). The relationship between internal integration and manufacturing flexibility in the Egyptian industry. International Journal of Quality and Service Sciences, 11(1), 16-33. https://doi.org/10.1108/IJQSS-06-2017-0052

Moliner, J.P., Cortés, E.C., Azorín, J.F.M., \& Tarí, J.J. (2012). Quality management, environmental management and firm performance: direct and mediating effects in the hotel industry. Journal of Cleaner Production 37, 82-92, http://dx.doi.org/10.1016/j.jclepro.2012.06.010

Nguyen, T., Pham, T., Phan, T., \& Than, T. (2020). Impact of green supply chain practices on financial and non-financial performance of Vietnam's tourism enterprises. Uncertain Supply Chain Management, 8(3), 481-494. DOI: $10.5267 /$ j.uscm.2020.4.004 
Oltean, F. D., Gabor, M. R., \& Conţiu, L. C. (2014). Relation between information technology and performance: An empirical study concerning the hotel industry in Mures County. Procedia Economics and Finance, 15, 1535-1542. doi: $10.1016 / \mathrm{S} 2212-5671(14) 00622-4$

Phan, A.C., Nguyen, H.A., Trieu, P.D., Nguyen, H.T., \& Matsui, Y. (2019). Impact of supply chain quality management practices on operational performance: empirical evidence from manufacturing companies in Vietnam. Supply Chain Management, 24(6), 855-871. https://doi.org/10.1108/SCM-12-2018-0445

Pirmanta, P., Tarigan, Z., \& Basana, S. (2021). The effect of ERP on firm performance through information quality and supply chain integration in Covid-19 era. Uncertain Supply Chain Management, 9(3), 659-666. DOI: 10.5267/j.uscm.2021.5.004

Prud'homme, B., \& Raymond, L. (2016). Implementation of sustainable development practices in the hospitality industry: A case study of five Canadian hotels. International Journal of Contemporary Hospitality Management 28(3), 609-639, DOI 10.1108/IJCHM-12-2014-0629

Ratna, S., Astuti, ES, Utami, HN, Rahardjo, K., \& Arifin, Z. (2018). Characteristics of tasks and technology as a driver of task-technology fit and the use of the hotel reservation information system. VINE Journal of Information and Knowledge Management Systems, 48(4), 579-595. https://doi.org/10.1108/VJIKMS-05-2018-0035

Shukor, AAA, Newaz, MS, Rahman, MK and Taha, AZ (2020). Supply chain integration and its impact on supply chain agility and organizational flexibility in manufacturing firms. International Journal of Emerging Markets, https://doi.org/10.1108/IJOEM-04-2020-0418

Siagian, H., Tarigan, Z.J.H., \& Andreani, F. (2019). The influence of information integration on hotel performance through the green operation and strategic purchasing. Proceedings of 9th International Workshop on Computer Science and Engineering, Hong Kong, 15-17 June, 26-31, doi:10.18178/wcse.2019.06.005

Siagian, H., Tarigan, Z.J.H., \& Jie, F. (2021). Supply chain integration enables resilience, flexibility, and innovation to improve business performance in COVID-19 era. Sustainability, 13, 4669. https://doi.org/10.3390/su13094

Sundram, V.P.K., Chandran, V., \& Awais Bhatti, M.A. (2016). Supply chain practices and performance: the indirect effects of supply chain integration. Benchmarking: An International Journal, 23(6), 1445-1471. https://doiorg.ezproxy.dewey.petra.ac.id:2443/10.1108/BIJ-03-2015-0023

Suprapto, W., Tarigan, Z.J.H., \& Basana, R.S. (2017). The influence of ERP system to the company performance seen through innovation process, information quality, and information sharing as the intervening variables. ICEMT '17: Proceedings of the 2017 International Conference on Education and Multimedia Technology, 87-91, doi.org/10.1145/3124116.3124131

Tarigan, Z., \& Siagian, H. (2021). The effects of strategic planning, purchasing strategy and strategic partnership on operational performance. Uncertain Supply Chain Management, 9(2), 363-372. DOI: 10.5267/j.uscm.2021.2.006

Tarigan, Z.J.H., Jiputra, J.A., \& Siagian, H. (2021). The effect of supply chain practices on retailer performance with information technology as moderating variable. International Journal of Data and Network Science, 5(1), 47-54, DOI: 10.5267/j.ijdns.2020.11.003

Tarigan, Z.J.H., Tanuwijaya, N.C., \& Siagian, H. (2020). Does top management attentiveness affect green performance through green purchasing and supplier collaboration?, Academy of Strategic Management Journal, 19(4), 1-10

Truong, H.Q., Sameiro, M., Fernandes, A.C., Sampaio, P., Duong, B.A.T., Duong, H.H., \& Vilhenac, E. (2017). Supply chain management practices and firms' operational performance. International Journal of Quality \& Reliability Management, 34(2), 176-193. https://doi.org/10.1108/IJQRM-05-2015-0072

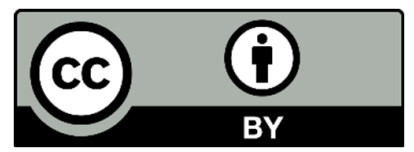

(C) 2022 by the authors; licensee Growing Science, Canada. This is an open access article distributed under the terms and conditions of the Creative Commons Attribution (CCBY) license (http://creativecommons.org/licenses/by/4.0/). 